\section{Changing the shape of geomorphology}

\section{Kidson}

The Nature of Geomorphology.

By Alistair F. Pitty.

Methuen: 1982. Pp.160. Pbk £3.95, $\$ 6.95$.

Process and Landform.

By Alan Clowes and Peter Comfort.

Oliver \& Boyd/Longman: 1982. Pp.290. £4.95, \$9.95.

Geomorphological Field Manual.

By V. Gardiner and R. Dackombe.

George Allen \& Unwin: 1982. Pp.272.

Hbk £16, \$30; pbk £7.95, \$15.

THE RATE of change of science is now so fast that a periodic re-statement of aims and objectives in each of its component disciplines is essential. Geomorphology is no exception to the general necessity. In this context it is most appropriate that Alistair Pitty has attempted to review the current status of the field.

No one would, in 1983, view geomorphology in the light of, for example, Wooldridge and Morgan's The Physical Basis of Geography: An Outline of Geomorphology (Longmans Green, 1937). In many respects, however, the earlier volume was a successful presentation of the state of the art at that time. The Nature of Geomorphology, by contrast, falls far short of reflecting the whole spectrum of geomorphological studies in the 1980 s. In place of the careful and systematic reviews to be found in The Physical Basis of Geography, the reader is given a rambling, and sometimes confused, philosophical apologia which spends far too much time on pondering whether this part of the subject falls within the field of geology or of geography, and on whether or how geography relates to the social sciences.

While noting the swing to process studies and quantitative methods in the 1950s and 1960 s and away from the earlier overemphasis on "stage" or time in Davisian geomorphology, Pitty fails to give due weight to the swing back of the pendulum represented by the large number of geomorphologists who are now much concerned with Quaternary chronology. The closest he comes to recognizing this aspect of the subject is the almost regretful statement that "contemporary geomorphology's strengths are ringed around its multidisciplinary periphery rather than congregated at its formal core"'.

In Process and Landform Clowes and Comfort attempt a similar task to Pitty but at a rather lower level, that of the sixthformer and the College of Education student. The format of the book has the merit of Wooldridge and Morgan's approach of systematically treating each area of the subject in turn. In many ways it is an exercise in presenting to schools a digest of research at university level, and insofar as it succeeds in this it may be of value to first-year university students. Unfortunately in places it is less than successful and shows some of the worst aspects of basing school lessons on half-digested undergraduate lecture notes. The diagram on "Britain During the Pleistocene Glaciations"' (on p.202) exemplifies this failing. It is, in other words, a useful text but not without serious blemishes.

The systematic presentation of material in Gardiner and Dackombe's Geomorphological Field Manual is also in sharp contrast to the style of The Nature of Geomorphology. The authors' aim is to provide an aide mémoire rather than a manual of field techniques. In this they succeed admirably, although not every field geomorphologist would agree with their choice of material. As in the Pitty volume the emphasis is heavily on process studies, the only concession to the role of time being a very short paragraph on the collection and storage of samples for ${ }^{14} \mathrm{C}$ dating. Nevertheless the Manual represents a useful contribution to field work in that part of the subject to which it relates.

Any layman attempting to understand contemporary geomorphology by reading these three texts would find some enlightenment. Many geomorphologists performing the same exercise might be dissatisfied with some aspect of each.

C. Kidson is Professor of Physical Geography and Head of the Department of Geography at the University College of Wales, Aberystwyth.

\section{The geologist at the restaurant}

\section{Keith Bell}

Putnam's Geology, 4th Edn.

By Edwin E. Larson and P.W. Birkeland. Oxford University Press: 1982. Pp. 780. 12.50, \$25.95.

Earth, 3rd Edn.

By Frank Press and Raymond Siever. W.H. Freeman: 1982. Pp. 610.

Hbk \$25.95, £20.50; pbk £11.95.

Physical Geology, 6th Edn.

By L. Don Leet, Sheldon Judson and

Marvin E. Kauffman.

Prentice-Hall: 1982. Pp.483. $\$ 30.75, £ 24.60$.

IT IS somewhat surprising, considering the scope of the earth sciences, that writers of modern, introductory textbooks broadly agree on what should be taught, what should be emphasized and the depth to which such material should be covered. Although the ingredients are roughly the same, the selection of a text, like a favourite restaurant, depends on how the ingredients are handled, how they are prepared and how they are served. When three past winners enter a race it becomes subjective, a matter of taste, as to which menu should be chosen.

Putnam's Geology, first published in 1964 , is a readable book, written with dedication in a distinctive, appealing style that most students will find attractive. Two new chapters, one on the Solar System and one on energy and resources have been added to this new edition. Although profusely illustrated, the quality of the illustrations tends to vary and the removal of the colour plates from the main body of the text to the centre of the book is not an improvement. Overall, the book is thorough, fairly broad in scope and enjoyable.

The new edition of Earth, neatly divided into three broad areas covering the evolution of the Earth, surface processes and internal processes, includes such current topics as COCORP and overthrust belts, oceanic hot springs and preMesozoic drift that bring a feeling of currency, so often lacking in introductory texts. The line drawings are particularly good and a new, large-page format is used. Novel features include the skilful use of footnotes (so hated by editors) and selfcontained boxes, also found in the previous edition, that include such delicacies as "anchoring the isotherm" and "high pressure and shock experiments". The latter should appeal to the more curious student, without hampering the more general reader and detracting from the main body of the text. The quantitative handling of some of the data will also find favour among the science-stream students.

Lying somewhere between the two is Physical Geology, a streamlined volume, ideal for someone wanting a no-frills, head-on look at the earth sciences. Changes in the new edition include extensive revision of metamorphism and metamorphic rocks, and separate chapters on weathering and oceans. Relegation of sections about planetary bodies and space exploration to an appendix is somewhat puzzling, but at least such information is available. A sufficiently detailed table of contents allows most topics to be found quickly and easily.

Interesting features, common to all three books, are chapter summaries, geological glossaries (a boon to the non-scientist) and fairly extensive chapters on mineral resources and energy. Which to choose is difficult. Putnam's Geology is best described as plain, wholesome fare, Press and Siever's Earth as la nouvelle cuisine and Physical Geology falls in the "let's eat right to keep fit" category. Choosing any one of the three offerings would be gratifying - all have the potential for satisfying a hearty appetite.

Keith Bell is Professor of Geology at Carleton University, Ottawa. 